\title{
ANIMATE EARTH, SETTLER RUINS: Mound \\ Landscapes and Decolonial Futures in the Native South
}

\section{LEIGH BLOCH}

Agnes Scott College

(1D) https:/ / orcid.org/0000-0001-6805-0192

Wise Elders taught us that One Above thinks not with words and language, as do humans, but through movements and processes.

- Hakope, personal communication, April 19, 2020

Place-Thought is based upon the premise that land is alive and thinking and that humans and non-humans derive agency through the extensions of these thoughts.

—Vanessa Watts, "Indigenous Place-Thought and Agency amongst Humans and Non-Humans"

My friend Deb McGregor (Ojibwe, Whitefish River First Nation) always points out to me that we are really living in just the tiniest sliver of Anishinaabe history.

—Kyle P. Whyte, "Our Ancestors' Dystopia Now"

"You know," Hakope's voice spoke, distorted through my phone, "sometimes people picked up whole mounds and moved them." 
As an undergraduate student working on my thesis, it was only a few months prior that I had begun learning from Hakope, an elder and Heles-Hayv (Maker of Medicine) of Pvlvcekolv: a small, Native American community in the US South who claim Muskogee (Creek) identity. The mounds in question are earthworks and shellworks built by various Native American nations over the past six thousand years between the North American Gulf Coast and the Great Lakes, the Atlantic and the Ozarks. ${ }^{1}$ While I had imagined these structures to be fixed in place, I learned that some mounds migrate. Visiting mounds over the past decade with Hakope and other Pvlvcekolv people, I also occasionally noticed my teachers gathering pinches of soil or plants to bring home to their ceremonial space and gardens.

Our paths meandered through these landscapes, twisting along nature trails and circling around mounds. Soils_-and also glass beads, stone points, and ceramic sherds found on the earth's surface_circulated through descendant communities and were gifted to friends on either side of the Mississippi River. This movement was a far cry from the straight lines that I walked as an archaeologist conducting systematic surface surveys, my back aching from bending over and searching the ground, or the neat walls of excavation units carved into Cartesian grids transposed over sites (imagine the abstract space of graph paper imposed over land). Such techniques help document the spatial context of artifacts found - without which, as I tell my students, artifacts themselves have little to no scientific value for illuminating past peoples' lives. Yet these methodologies also fix Indigenous places and things within Eurocentric epistemologies and ontologies, or ways of knowing and being in place. They ironically immobilize traces of ancestral lives in the archaeological imagination even as they dislocate the archaeological record. Archaeological time, after all, is produced as soils and material traces migrate through excavation screens, labs, museums, and universities. These methods are premised on a logic of separation that severs knowledge of past people from my aching back and ebbing attention as I traversed the land in neat transects. While widely critiqued from feminist, postcolonial, Indigenous, and Marxist perspectives, these myths of separation continue to inform the basic methodological practices that generate the archaeological record.

However, some mounds migrate, refusing to be so fixed.

\section{INTRODUCTION}

In Alabama, along the Tallapoosa River, a dirt road winds between cotton fields littered with fragments of ceramics and glass, flaked stone, and the occasional bead. Just behind the tree line, through thick river cane, the earth rises into 
a tall mound overlooking the river. A historical marker sits down the way where the dirt road meets the highway. One side of the marker is written in English. The other is in Mvskoke (Creek).

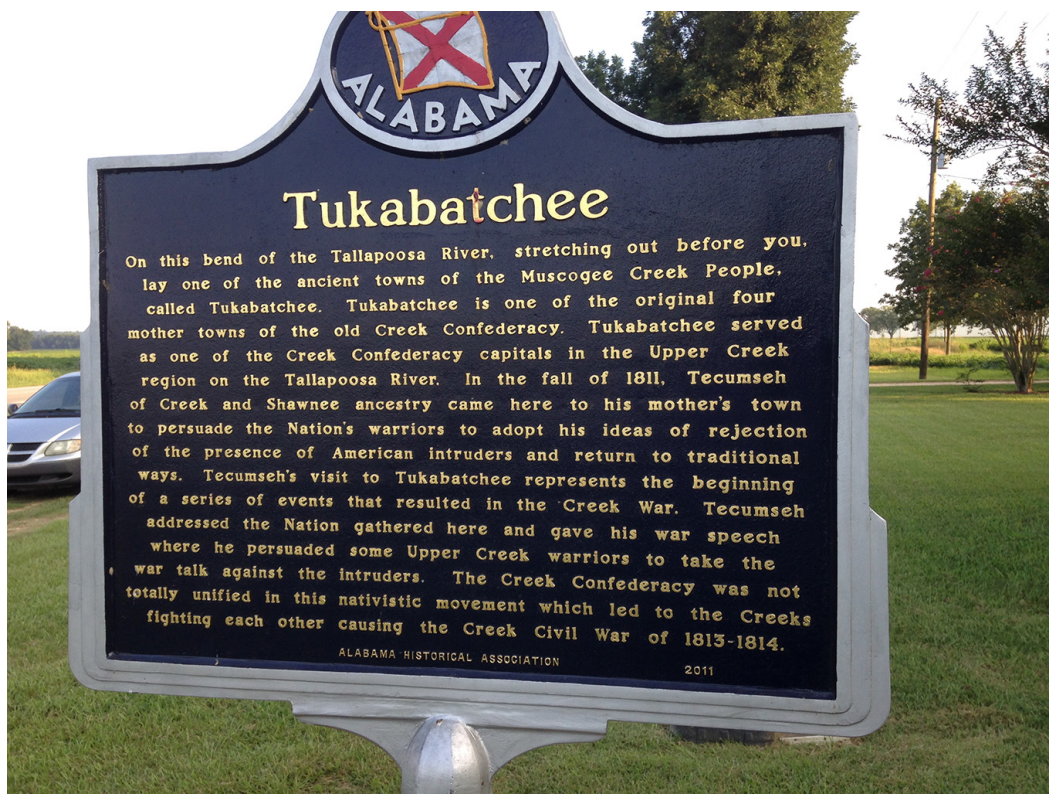

Figure 1.The English side of the historical marker at Tukabatchee. Photo by Leigh Bloch.

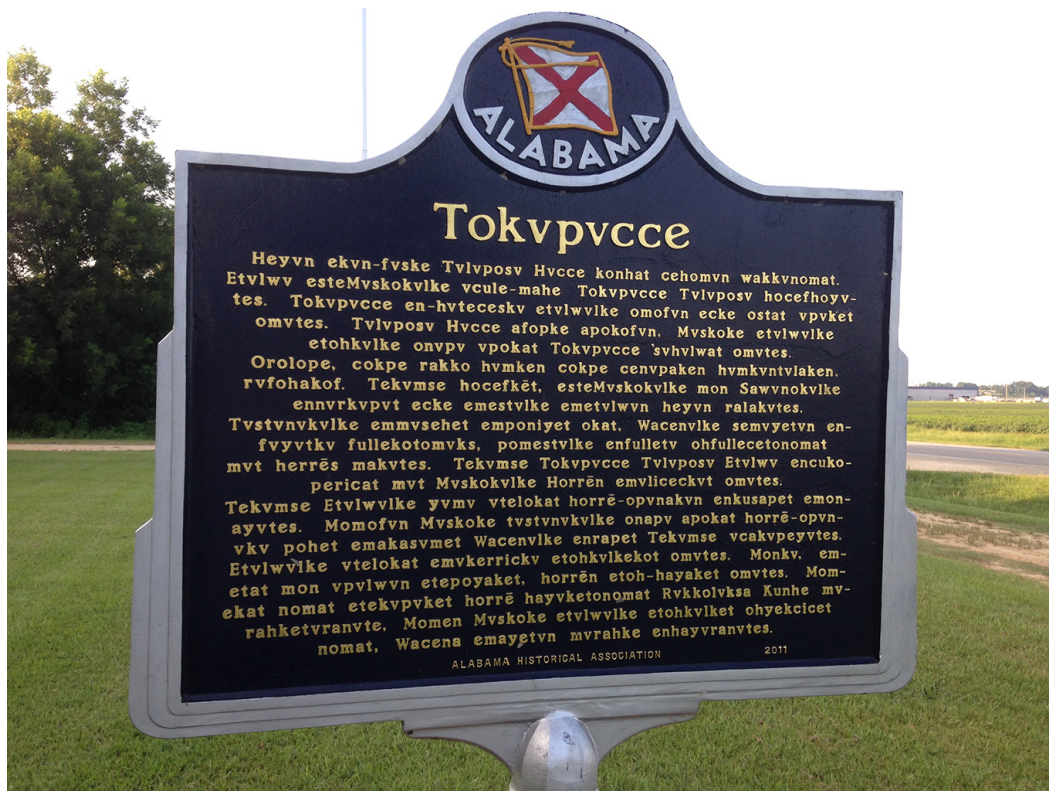

Figure 2. The Mvskoke side of the historical marker at Tukabatchee. Photo by Leigh Bloch. 
The marker informs readers that this place, Tukabatchee, was once the site of a powerful town in the Creek Confederacy. It was here that Tecumseh and Tenskwatawa, the Shawnee leaders and prophets, urged the Creek National Council to join their pan-Indian movement of spiritual renewal and military opposition to the expansionist United States. I am told that when the marker was written, authors from the Muscogee (Creek) Nation in Oklahoma had wanted to include a sentence at the end to the effect of, "Imagine what it would be like here if white people never came." This language was removed from the final text. Even so, an old site becomes a place for imagining alternative Indigenous futures.

Ancestral Native American peoples built thousands of mounds across eastern North America over the past six thousand years. Although important exceptions exist, archaeological research on mounds as a disciplinary project has been overwhelmingly organized around the assumption that these are "prehistorical" places, construed as terminal sites fixed within self-contained chronological periods. The Kuna and Rappahannock playwright Monique Mojica $(2012,219)$ writes: "How do I talk about realisms when definitions of realism (and what is perceived and presumed to be real) depend on my continued erasure, my vanishing outline against the 'preservation of archaeological remains/collection of data/confirmation of evidence,' of language and signage that declares our cultures 'abandoned' as they 'fell into decline'?" The scientific realism that dominates archaeology in settler colonial contexts relies on the erasure of Indigenous bodies and presence. In contrast, Mojica writes of drawing the living forces of ancestral ceremony into her body, as an archive of knowledges and dramaturgies sedimented within the earth, and extending these through her performance art. Like the alternative futures imagined at Tukabatchee, such practices exceed what Mark Rifkin (2017) calls settler time: a concept that names the temporal dimensions of elimination practices (including physical genocide, displacement, forced assimilation, and symbolic erasure) at the heart of settler governance. This foreclosure of Indigenous life renders land dispossessable as the very condition of possibility for settler society, law, and wealth. Settler time reduces mounds to prehistorical spaces and abandoned ruins within regimented, linear temporalities: in short, places without future. It organizes the Indigenous past around a Eurocentric history/prehistory divide that obscures longer Indigenous processes (Lightfoot 1995; Scheiber and Mitchell 2010; Schmidt and Mrozowski 2013; Schneider 2015) and fixes mounds within a terminal past removed from a settled present. Yet mounds continue to draw descendants into ancestral lives and movements, insisting on specifically Indigenous futures. 
This article theorizes the contradictions and convergences between colonial power and what I call mound power, attending to deep histories and slow processes as they animate social possibility and hope in an era of proliferating apocalypses. Ann Laura Stoler (2008) notes that the material ruins of empires exercise force in the longue durée and calls on researchers to attend to the slow processes of colonial power that exceed the timeframes of bureaucratic state apparatuses. Settler power specifically, however, already constitutes a process of ruination. It both constructs Indigenous landscapes as prehistorical ruins and itself enacts apocalyptic, political-ecological catastrophes. These forces include what is often called the Anthropocene, although the term risks artificially separating environmental destabilization from violence enacted on Indigenous bodies, ancestors, and landscapes as expressions of settler power. As Indigenous critics argue, environmental destabilization is not a new or future event, but a world-ending historical process that has been unfolding for the past several centuries and that interrupts placebased, more-than-human knowledges and relationships (Davis and Todd 2017; Whyte 2017). In a third sense of ruination, settler states themselves eventually collapse and crumble. Archaeologically speaking, the nature of the state is to collapse. A deep historical perspective illuminates these processes and the possibility of an afterward. While such afterlives may not be free from the long-term effects of colonial power, they will differ substantially.

The operations of settler power are both countered by and entangled within mound power, which similarly operates in the longue durée. By "mound power," I mean the force relations exercised by mound landscapes as not simply dead spaces, but as animate beings in their own right (Mojica 2012). Working from Anishinaabe and Haudenosaunee oral traditions, Vanessa Watts (2013) argues that the land is alive, intentional, and thinking. These earthly thoughts find expression as the embodied agency of human and nonhuman beings. As sentient landscapes, mounds are vulnerable to ongoing colonial violence. Mounds may erode or be leveled by tilling or development. Many have been mined for dirt fill in the construction of train rails and highways, literally powering settler economies through Indigenous sacred places and ancestors. But mounds also endure, even as cement infrastructure around them cracks and crumbles. Wounded by colonial violence, mounds call on descendants to provide care, interpolating them into the deep durations and patient processes of ancestral movements. ${ }^{2}$ These deep temporalities expose the radical hubris of the colonial project, with its claims of encompassment and finality and its presumption of defining the scope of possible futures. Mound power 
breathes life into Indigenous futures that emerge within the ruins of empires, offering hope for resurgent modes of life beyond settler nation-states.

Colonial discourses fix mounds within a terminal past removed from a settled modernity. In this way, Removal is not just a historical event, but an ongoing process and temporal structure (Wolfe 2006; Rifkin 2017) that organizes violence against Indigenous landscapes and ancestors. Yet mounds also refuse to be fixed within settler time, insisting on Indigenous futures. Refusal, as Audra Simpson (2014) theorizes it, marks an act of saying "no" to the terms of interpolation set by colonial states that asserts the power to define Indigenous sovereignty, or the scope of self-determination as peoples and nations, beyond the limits of settler practices of legibility or recognition. While liberal settler regimes demand Indigenous peoples' articulate sovereignty in ways that are legible to - and reproduce - the model of the nation-state, this does not constitute the limit of Indigenous nationhood (Coulthard 2014; A. Simpson 2014). Mound power extends refusal beyond the human, foregrounding the agentive forces of ancestral landscapes. In this context, mounds enroll descendants into ancestral movements and nonlinear temporalities, enacting Indigenous sovereignties as embodied and emplaced expressions of earthly intentionality (Watts 2013). These political formations are not structures but processes animated by mound power that unfold in deep and nonlinear time.

At times, settler and mound power contradict each other; at others, they appropriate, re-appropriate, and redirect one another to animate their own projects. This framework helps theorize alternative Indigenous and decolonizing archaeologies as a practice of caring for wounded landscapes within slow processes in which empires collapse and crumble. For this, we need theories of how the land and the dead become vulnerable to ongoing colonial violence in the fractures of liberal settler regimes of recognition, as well as in Indigenous practices of caring for wounded landscapes and outlasting settler states. By liberal settler colonialism, I mean policies and practices that extend selective federal recognition and accommodate narrow, confined spaces for Indigenous self-determination encompassed within settler nation-states, that is, in which pluralistic settler states "seek to 'reconcile' Indigenous assertions of nationhood with settler-state sovereignty via the accommodation of Indigenous identity claims" (Coulthard 2014, 3).

\section{COMMUNITY-BASED RESEARCH IN THE PVLVCEKOLV COMMUNITY}

Since 2010, I have conducted community-based research visiting some threedozen ancestral sites with Pvlvcekolv people. ${ }^{3}$ Indigenous and community-based 
archaeologies call on researchers to re-center theory and practice within Indigenous communities, values, oral traditions, epistemologies, and ontologies (Watkins 2000; Smith and Wobst 2005; Atalay 2006; Colwell-Chanthaphonh and Ferguson 2008; Silliman 2008). As these methods gain widespread acceptance, practitioners increasingly ask how they might advance a theoretical agenda (McNiven 2016; Cipolla, Quinn, and Levy 2019). I address this question by adopting an ethnographic approach (Dowdall and Parrish 2003; Ferguson and Colwell-Chanthaphonh 2006; Laluk 2017) that attends to alternative archaeologies (or ways of knowing the deep past and renewing relationships with ancestral presences) already practiced within descendant communities, which may differ from how archaeology is usually imagined at this particular moment in time. I draw on ethnography as a methodology adapted for identifying contradictions between dominant discourses and local knowledges, or "life on the ground." At the same time, many community members have taken archaeology classes in college. Some attend archaeology talks often, seeing these as important if often problematic sources of information about ancestors. Sometimes new research will even trigger memories of oral traditions that elders had not thought about since childhood (Bloch 2018, 136-41). I argue that mound landscapes enroll descendants into circulations of tangible and intangible heritage that generate multiple, at times competing, temporalities. This framework encompasses but is not exhausted by traditional archaeological methods and theories.

This research began on the invitation of the community's leadership. As an undergraduate student, I presented a conference paper critiquing the gender binary in interpretations of Birdman and Birdman figures in Mississippian Period art (c. 1000-1600 CE). A community member in attendance passed my paper to the leadership, who invited me to attend a ceremonial gathering, called a busk. There, I learned that Pvlvcekolv people interpreted these same figures as moths (Bloch 2014). This set the tone for my graduate studies. At the risk of underplaying the complexities involved, a ceremonial leader saw my role as an opportunity to "set the record straight" by advancing an archaeological perspective centered in Indigenous cultural frameworks (Smith and Wobst 2005; Atalay 2006). Over the years, I have also been asked to help with Pvlvcekolv cultural revitalization efforts, especially by recording knowledge from elders and creating archival records for future generations. For example, in the early years of my research, Hakope asked that I document a funeral, stating that the departed's children and potential future grandchildren would appreciate such a record in decades to come. This document was subjected to several rounds of community reviews in which my hosts and 
teachers rejected early drafts and pushed me to work through my own existential (and ethnocentric) anxieties about death. Yet while I often felt a need to provide tangible benefits that utilized my academic training, for many of my teachers, my research was just as much an opportunity to take weekend trips with family and friends to visit mounds. On these trips, people had fun, strengthened community, and at times cared for ancestors.

Historically, the Muskogee Confederacy was made up of several dozen tvlwv, or towns (Ethridge 2003; Foster 2007). Each maintained a high degree of political autonomy. The ancestors of Pvlvcekolv people avoided Removal in the nineteenth century, in which the United States forcibly marched Creek and other Native American nations to Oklahoma. As such, the Pvlvcekolv community remains distinct from the Muscogee (Creek) Nation in Oklahoma. The community is not federally recognized, nor are they actively seeking recognition. Some community members state that they simply want to live their life with minimal outside interference. The leadership holds that they can maintain greater autonomy by practicing the busk in private, beyond the gaze of the settler state and public. Elders describe busking as a means of honoring, acknowledging, renewing, and "giving breath" to the more-than-human world - a framework that has both ontological and political dimensions. In this way, Pvlvcekolv sovereignty primarily finds expression through busking - and mound power - as what Glen Sean Coulthard $(2014,65)$ calls a self-determining mode of life, rather than in direct relation to the settler state (Koons 2019).

\section{THE INDIGENOUS LONGUE DURÉE}

While I place my focus on mound landscapes in eastern North America, shell mounds in what is currently California provided places of refuge and memory for descendant peoples in the Mission Period (Schneider 2015). In such contexts, mound power animates a politics of flight from colonial institutions as a continuation of Indigenous mobilities that exceed the history/prehistory divide. In eastern North America, mounds likewise embody deep durations of movement and connectivity. Some mounds are massive, like Monks Mound in Cahokia's Grand Plaza. At thirty meters in height, the mound erupts out of the suburbs of East St. Louis, Illinois. The Grand Plaza was only one of many similar plazas, the rest of which were destroyed by urban development. Other earthworks house the dead or assume geometric or zoomorphic forms, such as the four-hundred-meter-long Serpent Mound in Ohio. 


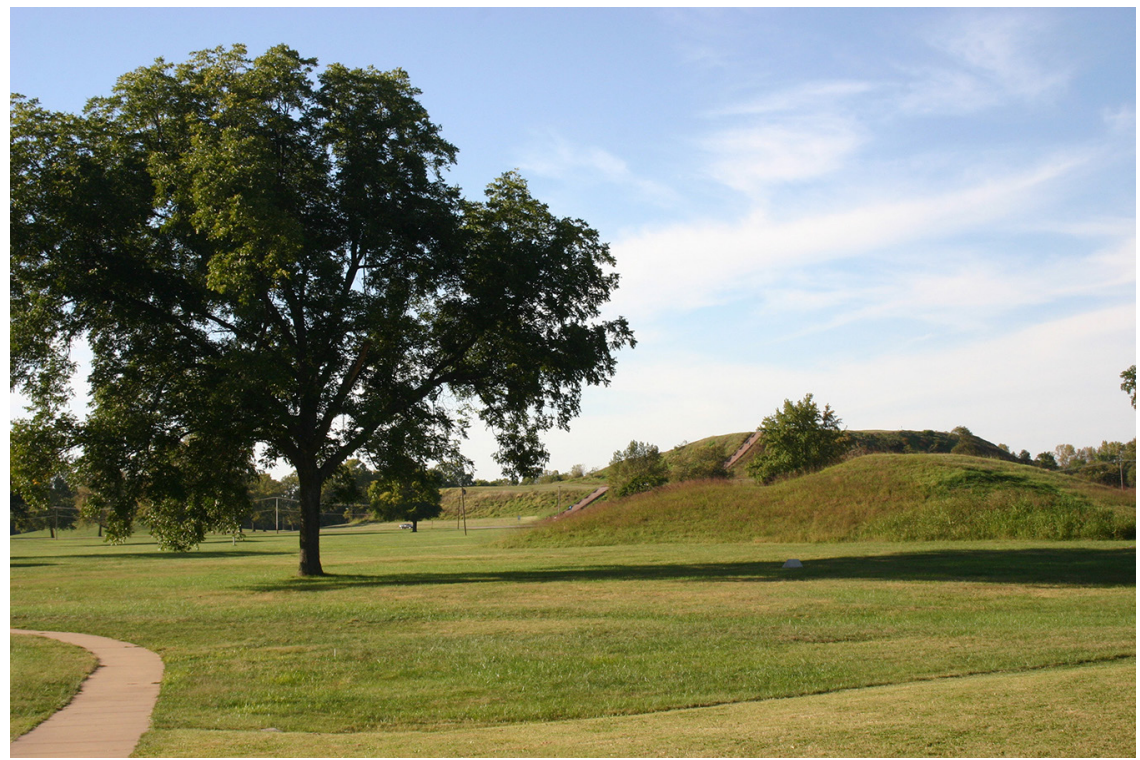

Figure 3. Monks Mound behind a smaller mound at Cahokia.

Note the car and telephone poles near the mound for scale. Photo by Leigh Bloch.

Mound building constitutes an expansive historical process, or longue durée, thousands of years in the making. ${ }^{4}$ The earliest archaeologically known mounds were built during the Middle Archaic period, about five thousand to six thousand years ago, in what has become Louisiana (Saunders et al. 2005). The material intensity of mound-building cycles throughout the following millennia, peaking next in the Late Archaic at the Poverty Point site in Louisiana (c. 1750-1000 BCE) (Ortmann 2010). Mound building intensifies next across the Midwest and Southeast in the Woodland Period, and especially the Middle Woodland (c. 200 BCE$500 \mathrm{CE}$ ). These sites were connected by interregional networks that carried goods such as copper, marine shell, pearl, mica, and stone over immense distances. The fourth peak in material mound construction occurs in the Mississippian Period (c. 1000-1600 CE). Both the Middle Woodland and the Mississippian refer not to a single phenomenon, but a broad, interregional process shaped by a multiplicity of local histories and complex interactions between many peoples (Carr and Case 2006; Pauketat 2007).

The Poverty Point site illustrates this deep history on a site level, as a place of return in which descendants repeatedly renewed relationships with ancestors across spans of thousands of years (Howe 2014). The immediate built landscape consists of six mounds and six concentric, kilometer-long, semicircular earthen 
ridges, most of them constructed during the Late Archaic. Yet diagnostic projectile points indicate human presence as far back as circa 13,500-11,000 BP. Moreover, the earthworks were built according to a geometric plan that incorporates two Middle Archaic mounds built two millennia before the Late Archaic component, which sit 2.4 kilometers to the south and 1.7 kilometers to the north, respectively (Clark 2004; Sassaman 2005). People returned to Poverty Point again around 1100-1150 CE and constructed the most recent mound (Ortmann 2010, 674). Contemporary Native American people of many nations continue to visit the site (Mojica 2012; Howe 2014; Bloch 2019). The Choctaw novelist LeAnne Howe (2014) interprets the largest mound at Poverty Point as a hawk that embodies teachings told in more-than-human bodies and relations. Hakope interprets the form of the large mound and ridges as representing a horned owl, noting that a number of miniature owl-shaped beads and pendants have been found at the site (Bloch 2019). When Hakope described oral traditions about traders who visited an "owl-shaped village" on their way to places like Cahokia, another Pvlvcekolv elder pointed out that, archaeologically, Cahokia dates to several thousand years after the bulk of Poverty Point. Hakope suggested that traders may have visited the site as a place of power long after the Late Archaic.

This deep historical perspective renders the colonial project a fleeting moment in comparison, exposing the radical hubris of its self-aggrandizing vision of totalizing encompassment, mastery, and control.

Yet chronology as a way of seeing also bounds and brackets mounds in linear time and bounded periods with beginning and end points. These foundational methods risk obscuring Indigenous temporalities and ways of knowing. For example, researchers in the Southeast have posited a "Mississippian shatter zone" (Ethridge and Shuck-Hall 2009) to explain the shift from complex, hierarchical chiefdoms in the Mississippian era to the consensus-, persuasion-, and confederacy-based political orders of the early colonial period. This transformation is understood as an effect of widespread collapse and destabilization resulting from disease, slave-trading, and nascent capitalism. Opponents of the concept point to the limits of the chiefdom model and the conflation of continuity with the stability of political institutions as understood from elites' perspectives, suggesting that it is better to work backward from the better-documented political structures of the colonial era (Foster 2007). Indeed, models of chiefly power were originally derived from functionalist accounts of Polynesian societies (Pauketat 2007), so the appearance of discontinuity potentially reflects a methodological problem. Yet both the shatter zone and the counter models naturalize settler time, defining continuity in terms 


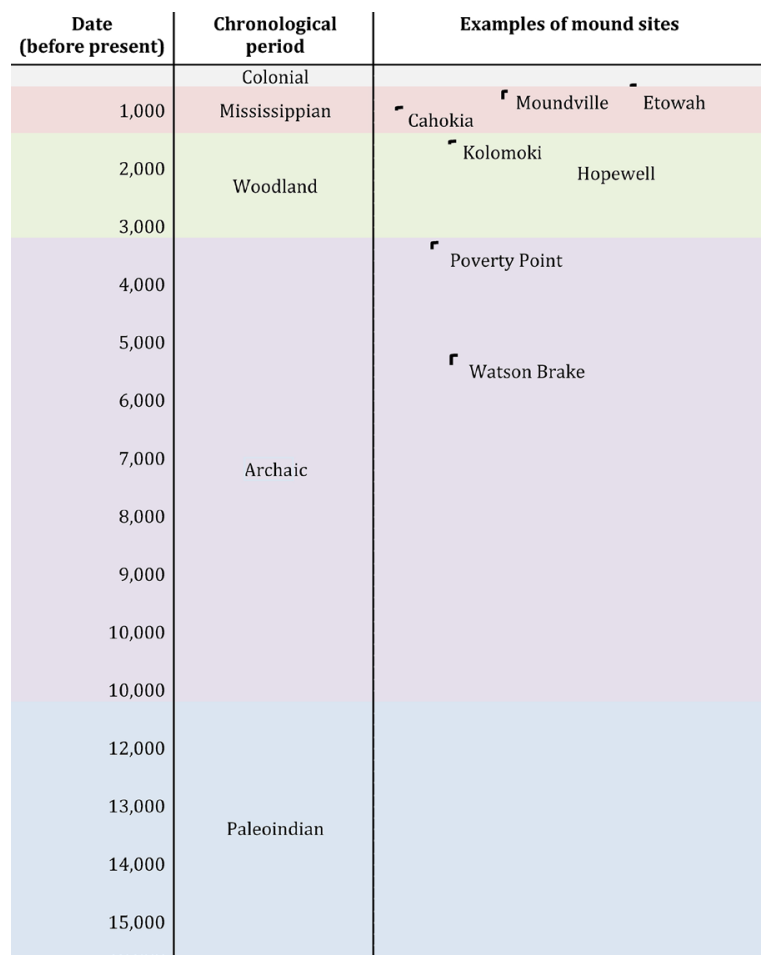

Figure 4. An archaeological chronology of the Eastern Woodlands.

Note that the Colonial Period is only a small sliver of Indigenous history. Image by Leigh Bloch.

of stasis between distinct chronological points. This precludes the temporalities of Indigenous governance vis-à-vis mound power that operate through nonlinear processes of return and renewal. The effect is a teleological narrative in which the lives of mounds - and even the Mississippian — are already over.

Pvlvcekolv people see mounds as living and sentient landscapes (see also Mojica 2012; Howe 2014; Allen 2015a, 2015b; Miller 2015; and more generally Cruikshank 2005; Watts 2013; Laluk 2017; Larsen and Johnson 2017). They draw descendants into deep histories that might lead in other directions, deflating teleologies that cast mounds as sites of finished pasts subsumed by colonial orders as the apex of human progress.

\section{MIGRATING MOUNDS}

To build a mound, one usually imagines starting from the bottom and working one's way up. Building the middle first seems unnecessarily difficult. Based on this assumption, an archaeologist might date a mound from samples taken from 
the bottom and top strata: The first construction event occurred at $\mathrm{X}$ point in time and the final layer of earth was added at Y later date. Fixed in time and space, this approach leaves no room for mounds to move about.

There is a place in Florida off I-10, a Mississippian site behind the storefronts and residential neighborhoods of Tallahassee. Seven mounds, conventionally dated to about 1000-1500 CE, sit enclosed within a state park and private lots (Jones 1982, 20-22; Payne 1994, 260-72; see also Marrinan and White 2007; Marrinan 2012; Seinfeld et al. 2015). Often called the Lake Jackson site, Pvlvcekolv people also call it Okeeheepkee. ${ }^{5}$ In the 1970s, a local landowner, Sam Crowder, decided to build a machine shop where Mound 3 stood. When the State of Florida did not follow up on negotiations to acquire the land, Crowder began to level the mound and sell the dirt as fill. Another landowner found an artifact in purchased soil and called the state archaeologist, B. Calvin Jones. In this complex regime of attention and bureaucratic, object-oriented care structured by settler formulations of private property and national heritage, Jones began salvage excavations on what remained of the mound (Jones 1982).

Mound 3 housed two-dozen burials and was built in twelve construction stages. Radiocarbon samples from the pre-mound ground surface and final construction cap provided calendar dates of $1293 \pm 71$ and $1540 \pm 75 \mathrm{CE}$, respectively. ${ }^{6}$

Table 1. Radiocarbon dates from Mound 3 at Okeeheepkee, or the Lake Jackson site

\begin{tabular}{|c|c|c|c|}
\hline Context & Material & Raw date & Calibrated date \\
\hline Burial 17 fill & Charcoal sapling & $850 \pm 70 \mathrm{BP}$ & $1152 \pm 80 \mathrm{CE}$ \\
\hline Feature 1 & Charcoal fire basin & $365 \pm 75 \mathrm{BP}$ & $1540 \pm 75 \mathrm{CE}$ \\
\hline \multicolumn{4}{|l|}{ Mound cap } \\
\hline Burial pit 1 & Charcoal sapling & $1025 \pm 80$ & $1012 \pm 98 \mathrm{CE}$ \\
\hline \multicolumn{4}{|l|}{ Floor $1^{\mathrm{a}}$} \\
\hline Burial 3 fill & Charcoal zone, $50 \mathrm{~cm}$ thick & $720 \pm 70 \mathrm{BP}$ & $1293 \pm 67 \mathrm{CE}$ \\
\hline \multicolumn{4}{|l|}{ Floor $1^{\mathrm{a}}$} \\
\hline Structural log & Charcoal, upright structural post & $1045 \pm 75$ & $992 \pm 91 \mathrm{CE}$ \\
\hline \multicolumn{4}{|l|}{ Floor 2} \\
\hline Burial 7 fill & Charcoal sapling & $550 \pm 90 \mathrm{BP}$ & $1372 \pm 59 \mathrm{CE}$ \\
\hline \multicolumn{4}{|l|}{ Floor 9} \\
\hline Burial pit 2 & Charcoal sapling & $1035 \pm 80 \mathrm{BP}$ & $1003 \pm 98 \mathrm{CE}$ \\
\hline \multicolumn{4}{|l|}{ Floor 10} \\
\hline Burial 6 fill & Charcoal from fill & $620 \pm 60 \mathrm{BP}$ & $1343 \pm 44 \mathrm{CE}$ \\
\hline \multicolumn{4}{|l|}{ Floor 11} \\
\hline Pre-mound midden & Charcoal from post & $715 \pm 85 \mathrm{BP}$ & $1293 \pm 71 \mathrm{CE}$ \\
\hline
\end{tabular}

Sources: Data derived from Jones (1982); Marrinan (2012); Marrinan and White (2007).

Notes: ${ }^{a}$ See Jones (1982, Table 1). 
Based on these samples, one can create a hypothetical model of linear mound construction in which Mound 3 was built continuously across this timeframe, with a new layer of soil being added every twenty years or so.

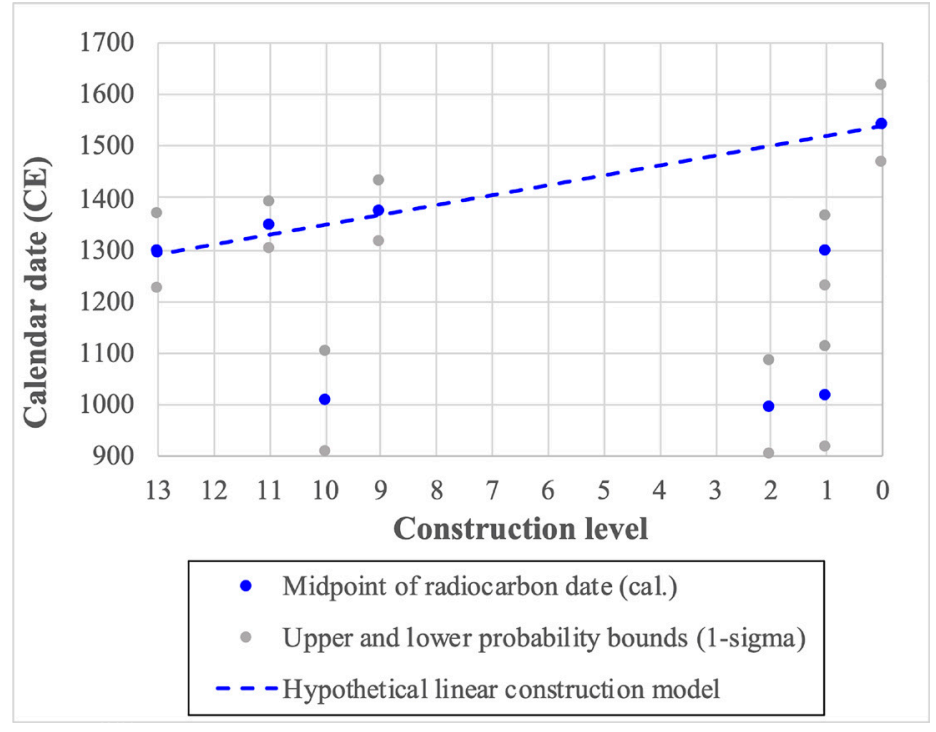

Figure 5. Hypothetical linear construction model of Mound 3 at Okeeheepkee. Image by Leigh Bloch.

Several radiocarbon dates associated with intermediate strata fit this model well. However, three dates associated with strata 1, 2, and 10 cluster around the turn of the eleventh century, long before the mound was supposedly built. B. Calvin Jones $(1982,21)$ simply notes, “These early dates are difficult to explain.” How strange that the middle of the mound would be built before the base!

Trying to make conversation, I asked Hakope what he made of these dates (Bloch 2014, 92-93). He thought for a moment and suggested: "Perhaps the dates came from wood reused from older structures. This would be easier than preparing new timber. Or they could have come from secondary burials." Indeed, traces of poles with one internment could represent a burial litter (Jones 1982, 11).

Hakope paused for a minute, thinking. "You know," he continued, "sometimes people picked up whole mounds and moved them.”

I chuckled to myself, imagining a group of people lifting up a mound and carrying it away. It took a moment to sink in. "You mean with baskets?"

"Yes, with baskets," Hakope replied. He suggested that Mound 3 could have been what he called a "bird mound." Bird mounds migrate: they are periodically 
moved from location to location. They can either be visible or unseen structures. Indeed, the borrow pits around Okeeheepkee-depressions created as ancient peoples gathered soil - are too small to account for the quantity of earth needed to build the mounds (Jones 1982, 5).

Migrating mounds foreground movements of soils that exceed clear temporal and spatial boundaries. They are not fixed in place. They are not static and inert. They are not even built bottom first. Instead, they migrate. The people of Okeeheepkee gathered up soil associated with circa $1000 \mathrm{CE}$ and drew this place into their lives on three separate instances centuries later. But the story does not end there. As Mound 3 was graded away, Pvlvcekolv people purchased some of this dirt fill from Crowder. They added it to their ceremonial space, called the stomp or Square Grounds.

And so ceremony continues to be danced on the soil of Okeeheepkee.

Migrating mounds draw attention not to monumentality but to memory and movement: to landscapes that move about and places that are simultaneously here and elsewhere. I later learned that Pvlvcekolv people have taken pinches of soil from mound sites across the region to add to their Square Grounds. With this in mind, I once gathered a bit of backfill from digs at two sites in Georgia as a gift. What I had assumed was a relatively simple act of transporting two Ziploc bags of dirt in the trunk of my car turned out to be much weightier. As an elderly woman explained, this was dirt steeped in the ceremonial forces of ancestors. Such matters of power are not without risk. The next day, an elder and retired professor, Simon, and I took up the task of adding the soil to a foot-tall mound in the center of the Square Grounds, the place where the fire sits. As we finished, Simon placed his hand atop the mound. "Feel the top of the mound," he directed me. "Do you feel the heat?" I reached forward and did so, surprised by the warm sensation. Simon said:

When this sacred place was recognized by the fire moving here, earth from many other towns was added to the mound . . . a kind of bringing back of a community of energies together. It's also a way for us to honor and recognize those places and the people who lived there . . we go to these old places that have been abandoned and may feel neglected and we recognize them, we honor them. Those places have spirits, too. And the spirits can get to feeling sort of forlorn. But I just have to imagine that those places that you mentioned, they'll be joining with us today when we do our busk work. 
As the soils of old places join the Pvlvcekolv Square Grounds, the living and the dead join in ceremony together. This provides a means of acknowledging and tending to ancestors, as well as joining in ancestral bodies and movements. Pvlvcekolv people also bury the umbilical cords of infants just east of the Square Grounds. When community members gathered twice in 2015 to do this, Hakope described it as an act of making the infants citizens of the town and one with the land (Bloch 2018, 213). This language makes Indigenous claims legible within colonial modes of governance (being "citizens of the land"), but they are not exhausted by these (belonging within political formations that extend from the land as an agentive, thinking being or milieu of relations) (see Bruyneel 2007, 106, 128). Should the community ever be forced to relocate, Hakope urged, they should gather up a bit of soil from this place to bring to the new Grounds.

Migrating soils weave seemingly distant peoples and places together, generating enfolded, non-Euclidean space-times (again, think graph paper as compared to the curvatures of general relativity or entanglements of quantum mechanics). Value hierarchies that privilege dates from the top and bottom strata of mounds obscure their historical depth, ongoing movement, and futurity, systematically underrepresenting their durations and misrecognizing Indigenous political formations. Moving beyond the assumption that earthworks are self-contained, bounded objects, migrating mounds take shape through acts of drawing other peoples, places, and times inward. Through these practices, descendants are enrolled into ancestral movements and Indigenous political formations that unfold within deep time.

These circulations generate multiple temporalities, whether mounds and their contents migrate through excavation screens and scientific instruments like accelerator mass spectrometers, the baskets and hands of ancestors, or the bodily movement of Pvlvcekolv ceremony danced on earth from Okeeheepkee. In this sense, migrating mounds constitute a practice of Indigenous archaeology much older than how the discipline is usually imagined.

\section{MAKING LIFE WITH THE DEAD}

Some mounds move; some move people. As I traveled across the Southeast with Pvlvcekolv people, I was struck by the number of mounds that have been graded away by plows, demolished to make way for development, and mined for dirt fill in the construction of railways and highways. Burial mounds have been and continue to be looted, desecrated, and appropriated as "treasures" and scientific specimens. Mound power is generative of settler orders, which depend on the appropriation and redirection of the force relations of Indigenous landscapes. Yet 
so, too, do the workings of capital open up unexpected Indigenous possibilities. As Mound 3 was commoditized and sold as fill, it also became available to Pvlvcekolv people for purchase. Pvlvcekolv people are able to share in the life-sustaining and healing forces of ceremony with Okeeheepkee-something all the more important in a context of burial violations. I want to hold on to this contradiction. It says something important about the ways of caring for wounded landscapes that become necessary in the ruins of settler colonialism.

Vulnerable to colonial violence and hurting, ancestors call out to Pvlvcekolv people through dreams, asking for companionship and care. One day, I traveled with several Pvlvcekolv families to visit Fusihatchee, a Muskogee Confederacy site in what is currently Alabama. Today, a small mound sits next to a dirt road and agricultural fields. The village site is now an open lake, created when the site was mined for gravel in the 1990s. Simon had visited this place a few weeks earlier and experienced a strange feeling: as if invisible hands were reaching out of the ground, pleading. This had proven a matter of some concern, and Pvlvcekolv families made plans to gather at the site. So I found myself standing on a dirt road that ran alongside fields of dried cotton stalks, the earth cracked under the August sun. About a dozen Pvlvcekolv people stood in the road wearing longcoats, a style of ceremonial dress, in spite of the heat. The smell of burning cedar filled the air as a thin trail of smoke wafted upward from a small fire. I shifted my weight from foot to foot, wondering if it would be inappropriate to turn on my recorder, and de-

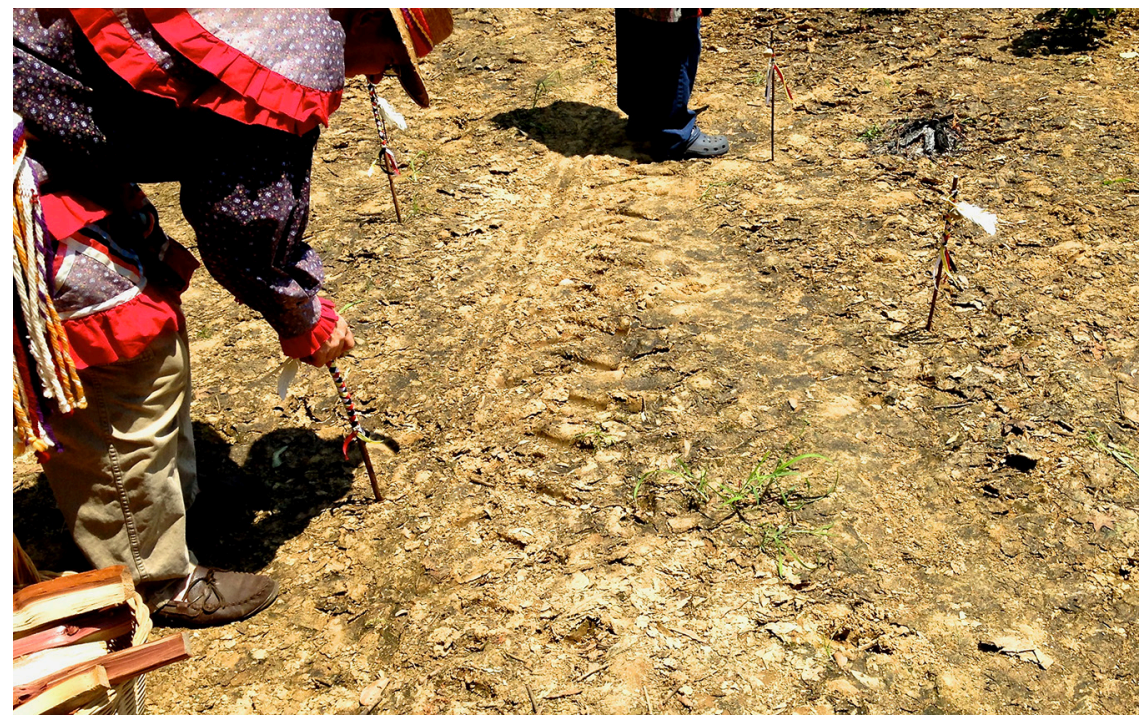

Figure 6. Pvlvcekolv people gather at Fusihatchee to care for the dead. Photo by Leigh Bloch. 
ciding against it. The men sang busk songs about snakes, birds, and healing. Then Hakope spoke, first in Mvskoke, then in English, about the four directions. Four people placed four small sticks braided with red, white, black, and yellow ribbons in the earth, upright in the four directions.

After another song, more words, and flute music, things finished. All in all, it took about fifteen minutes.

As others left for lunch, I lingered near the mound with Simon and another elder, Victor. A community friend and respected Creek and Choctaw pipe maker who scoured archaeological texts for inspiration, Victor had begun busking at the Pvlvcekolv grounds after his wife had died earlier that year. He said, "That was probably the first time Mvskoke has been spoken on this land in 150, 200 years." Later, Hakope told me that the purpose of the visit was to cleanse the land, removing corruption collected over centuries. However, he and others also told me that like any old person, ancestors sometimes got to feeling lonely, wishing relatives would call or visit more often. In this sense, the ceremonial proceeding was more fundamentally a gesture: a formal way of saying, simply, "You are still here, and you are important to us."

That night, several people had strange dreams. One man, Harry, described a woman tied to a wooden post, about to be executed. He next saw her as a corpse, her dried skin tight around her bones. Although dead, she opened her eyes, which were brilliant and shining. At first frightened by the eerie dream, Harry discussed it with others. They concluded that the dream was a message of affirmation. "It was good of you to visit us," those people at Fusihatchee seemed to say. "It is good of you to keep the Muskogee way going. It looked like it was dying, but it is still alive.” Pvlvcekolv people, like Indigenous people elsewhere, are concerned about the threat of cultural loss. Very few young people busk, and elders worry about the future. Ancestors like those at Fusihatchee share in this anxiety, but they also have the benefit of a deeper temporal perspective. They seem to say: "We, too, were worried that the Muskogee way had reached its end. Yet here you are."

It is not that mounds are abandoned, but that those buried within them are consigned to oblivion within the afterlife of Removal, which left too few kin in homelands to attend the dead. This constitutes the ongoing violence of Removal: a systematic neglect and loneliness inflicted on the dead. Ancestors are vulnerable to this violence because their very capacity to hurt is unthinkable within colonial orders of life and death, life and nonlife, in which they are legible only as inert remains and Tierra Nullius, empty and waiting. They go unnoticed and uncared for, except perhaps as scientific specimens, objects denuded of life. As Pvlvcekolv peo- 
ple return to mounds, they open their bodies to ancestral affects. A most intimate kind of contact, these may be felt as hands reaching up, pleading, or as dreams that take hold of Pvlvcekolv people's sleeping consciousness. Perhaps this is why my teachers say that their most important ceremonies are ways of acknowledging, and in doing so, renewing and "giving breath" to others. If to be alive is to be given breath by another, who is unacknowledgeable within settler regimes of recognition? Hurting, ancestors turn to descendants. And as the living and the dead find one another in mutual embrace, they breathe new life into Indigenous futures that both worried had been foreclosed.

\section{CARE IN THE RUINS OF EMPIRE}

Mound sites are vulnerable to colonial violence, but they also draw descendants into deep historical processes and specifically Indigenous futures. As a kind of Indigenous archaeology, these practices eschew teleologies that would declare the histories of mounds over and done with, privileging the loving labor of caring for ancestors and making life together within wounded landscapes. In this way, mounds animate what Rifkin (2017) calls sovereign Indigenous temporalities: a multiplicity of space-times tracked by durations and momentums that exceed the universalizing and Cartesian frames of reference of settler time. Wary of assimilating Indigenous peoples into a "shared now" of modernity defined by colonial encompassment, Rifkin is interested in other kinds of time. Such temporalities are sovereign in that they are autonomous from - if entangled with — settler time. But they also structure Indigenous political formations irreducible to liberal settler practices of federal recognition. As mounds migrate, they enroll descendants into ancestral movements that weave together seemingly distinct places and sites, extending ancestral lives forward in living ceremony-even reappropriating circulations of soils as settler landowners and states recognize small artifacts in dirt fill as cultural resources in need of documentation and preservation. Likewise, as the dead call out to descendants, their wounds remain unrecognizable within settler regimes of life and death and they enroll Pvlvcekolv people into specifically Indigenous futures. Mound power animates modes of life that extend from beings unrecognizable by settler regimes that cast ancestral bodies and landscapes as inert objects and remains, as an act of being interpolated into the deep durations of ancestral movements and political forms. This politics may not always directly challenge settler states, but it does generate spaces for flourishing with ancestors (L. Simpson 2011). 
The anthropology of care proves helpful here in theorizing both the ways people navigate the fractures and "zones of abandonment" of biopower (or state practices of managing populations and [unevenly] distributing life and death) (Biehl 2005) and caretaking practices irreducible to such regimes (Han 2012, 25-26). Lisa Stevenson (2014) asks what kinds of care do not disavow the others' autonomy and do not frame death as abject to life. In the context of the Inuit suicide epidemic, she problematizes health-care interventions that fix subjects as problems to be solved. Instead, she theorizes acts of "loving interpolation" that call others into presence, without fixing them in advance as a more modest work of sitting with others' wounds (see also Garcia 2010). This, she suggests, poses an alternative to bureaucratic mechanisms of regulating and enforcing life. In this same way, I am interested in mound power as it "unfixes" ancestral places from settler time and calls on descendant peoples to care for wounded landscapes, as an agentive force larger than settler dreams of mastery and control. Stevenson (2014) writes of moments when the living call out into absence and into death, such as yearning for family and friends who have ended their lives. However, at Fusihatchee, it is the dead who call out to the living. It is the land who interpolates my Pvlvcekolv teachers, animating political formations that enact what Stevenson $(2009,73)$ calls "a way of loving [that presumes] neither the certainty of life as ultimate value nor the discreteness of life and death."

However, Pvlvcekolv practices of caring for wounded landscapes and ancestors foreground the colonial relations on which biopolitics is premised and ways of acknowledging and attending to ancestors' hurt that exceed liberal settler regimes of recognition. Indeed, Pvlvcekolv people inhabit complex colonial regimes of acknowledgment, recognition, and abandonment. Unrecognized by the United States as a Native American nation, members care for wounds unrecognizable within settler realisms in places preemptively declared abandoned. A state archaeologist acts as a steward, if not caretaker, of mounds as national heritage and Pvlvcekolv people purchase soil from Okeeheepkee and extend ancestral dances forward. Biopolitical regimes of managing life depend on ontological, or what Elizabeth A. Povinelli (2016) calls geontopolitical, orders. By using the terms ontological and geontological, I point to questions and practices surrounding the nature of being as they relate to and order the functioning of state institutions, problematizing what Mojica (2012) might call the realisms of colonial governance. Settler governance is ordered through dichotomies of life/not-life (Povinelli 2016) and life/death (Stevenson 2014) that interpolate ancestral bones as inert objects denuded of life, rendering mounds as simultaneously abandoned places and vulnerable to the ongoing 
violence of systemic neglect. Pvlvcekolv practices of caring for land and ancestors operate within the fractures of these regimes, but they also animate ways of life irreducible to such logics. These practices are not simply acts of "self-making" but also of being interpolated into a self-determining mode of life (Coulthard 2014) by ancestors and land as an operation of power that contradicts, re-appropriates, and outlasts settler power.

These considerations articulate a practice of Indigenous archaeology that operates through acts of being drawn into ancestral movements and caring for wounded landscapes. These archaeologies create not only pasts but also futures. They may but do not always excavate; they may but do not necessarily create chronological periodizations or representations of the past. They do, however, generate affective entanglements that gather up seemingly distant persons, places, and moments and renew relationships with ancestors as a practice of Indigenous flourishing (A. Simpson 2014; Whyte 2017). Such a practice can draw on what Kenneth E. Sassaman (2012) calls futurology, which problematizes archaeology as the study of a past severed from the present and future and looks to long-term human processes for insight into contemporary problems such as climate change. Pvlvcekolv practices, however, demand a specifically decolonial futurology that challenges the commitment to the future of settler states that manage environmental problems (Tuck and Yang 2012), calling attention to what Grace L. Dillon (2012) terms "Indigenous futurisms" that extend from within folded, spiraling, and nonlinear temporalities (Whyte 2018). Such a decolonial futurology constitutes a practice of being drawn into the folded space-times of Indigenous land and governance, or teachings for living rightly with human and more-than-human relations (Alfred 1999; Watts 2013; Todd 2018) as an expression of earthly intentionality or mound power. It is a practice of making life with the dead and cultivating specifically Indigenous futures in the ruins of settler states.

\section{THE LAND, WOUNDED, HEALS ITSELF}

As Kyle P. Whyte (2017) writes, Indigenous peoples already live in their ancestors' dystopian futures. At Okeeheepkee and Fusihatchee, this is not just a speculative method but a visceral function of the ongoing violence of Removal. Following this critique, settler power operates through ruination in multiple senses (see also Stoler 2008; Dawdy 2010; Tsing 2015; Haraway 2016). First, dominant discourses construct mounds as sites of ruin. The privileging of mounds as prehistorical sites operates to naturalize settler time, removing Indigenous pasts from a settled modernity and erasing the operations of Indigenous governance via 
mound power. More than a "modern exceptionalism" that constructs modernity as severed from "before" (Dawdy 2010), this creates a specifically settler modernity premised on the foreclosure of Indigenous futures. Second, settler colonialism itself lays ruin to land via extractive economies. Mound landscapes and the ancestors who inhabit them are particularly at risk because their sentience and capacity to be wounded is impossible within settler orders of life/death and life/nonlife, in which land is inert and human remains are devoid of life. Such violence may take the form of disturbing ancestral remains, mining Indigenous sites to power the settler economy, or the systematic loneliness and neglect of post-Removal landscapes. This formulation extends anthropological theories of violence beyond life and beyond the human, attending to colonialism as an ecology (and afterlife) of proliferating apocalypses (Davis and Todd 2017; Whyte 2017). Yet as mound landscapes call on Pvlvcekolv people to provide care, ancestors and descendants make life together, carving out space for Indigenous futures within the ruins of settler power. Anna Lowenhaupt Tsing (2015) argues that even the ruins wrought by capitalist production can sustain surprising and unexpected forms of life. These are not separable from the operations of capital but may nonetheless resist regimentation. Yet mound power foregrounds the specific relationship between capital and settler colonialism, in which colonial relations of dispossession create the conditions of possibility for settler law and wealth (Wolfe 2006). This brings me to the final sense of ruination: Even as mounds are graded away or mined for fill, the seemingly permanent artifices of the settler state collapse and crumble, falling into ruin.

I once visited Horseshoe Bend with a Pvlvcekolv man, David. In 1813, the Creek Civil War erupted between the Red Sticks, a faction sympathetic to the prophet Tecumseh, and those allied with the fledgling United States. The latter called on Andrew Jackson for aid, and in 1814, the Battle of the Horseshoe Bend ended with Red Sticks' defeat. In the aftermath, General Jackson betrayed his allies, forcing the Creek Nation to cede 23 million acres of land: about two thirds of Creek country. Removal began just a little more than ten years later.

Here, at Horseshoe Bend, a refusal of the settler and capitalist order fell (Saunt 1999; Ethridge 2003). Yet as David and I walked about the site-now a national park - we were taken aback by the beauty and serenity of the landscape. Leaves crunched under our feet while ancient oaks stretched their branches over us. The earth sloped gently toward the snaking edge of the river. The remains of an old bridge stood before the newer roadway, in the slow process of collapsing into the Tallapoosa River. 


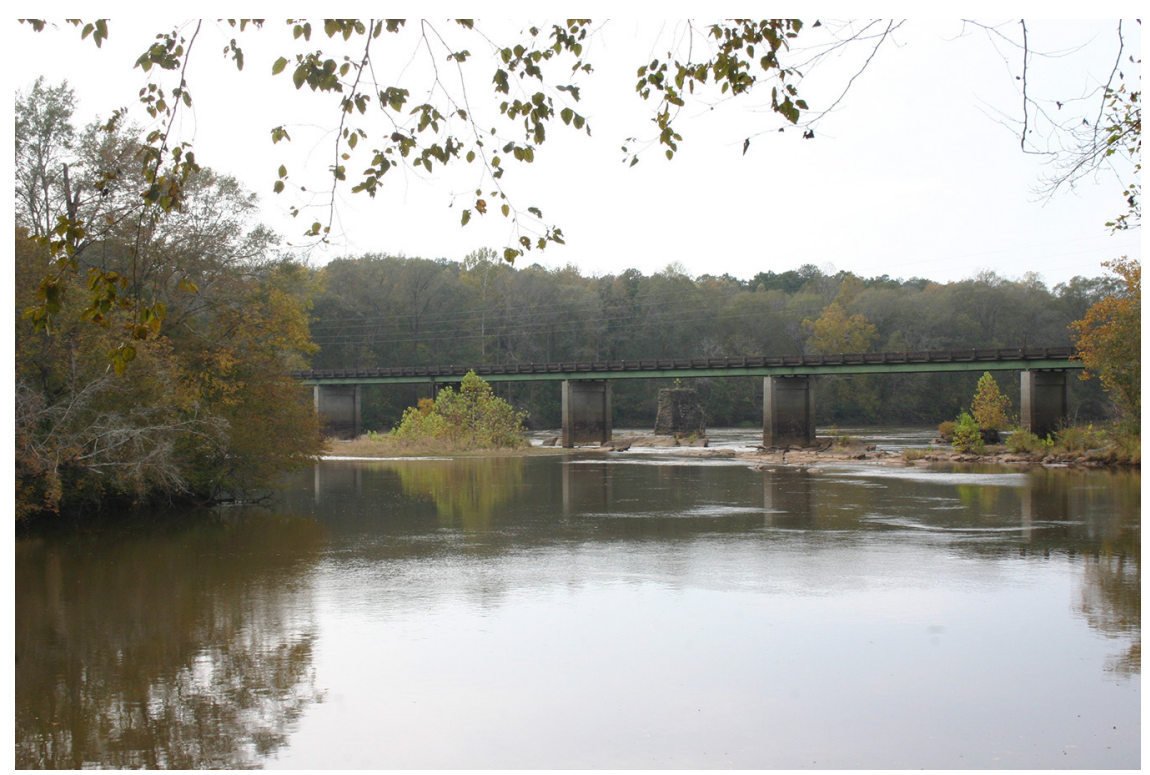

Figure 7. An old bridge falls into the Tallapoosa River at Horseshoe Bend. A new bridge has been constructed in front of it. Photo by Leigh Bloch.

"It's strange that a place with such a dark history could be so beautiful," I said. David pointed out how much sweetgum was growing in this place. In Pvlvcekolv teachings, sweetgum is the burden tree. An agent of healing and peacemaking, it takes up the heavy loads that people carry, their hurt and sorrow, so that they can be present with Creator's teachings and learn to live well together (Bloch 2018, 149-56).

"It's as if the land is healing itself," David said.

\section{CONCLUSION}

The land, wounded, heals itself.

As the land enrolls Pvlvcekolv people into circulations of soils and relationships of care, it animates Indigenous temporalities that dramatically exceed settler time, exposing the radical hubris of the colonial project. As sentient landscapes, mounds are vulnerable to ongoing colonial violence, whether in the form of grave looting, desecration, or systematic neglect. In turn, these places reach out to Pvlvcekolv people, asking for companionship, acknowledgment, and care. They animate a decolonial archaeology/futurology as a practice of being drawn into the operations of mound power: of renewing intimate relations with ancestral presences, caring for wounded landscapes, and reopening Indigenous futures to- 
gether. These practices may not look like the kind of disciplinary norms that most have come to expect, demanding a rethinking of what counts as archaeology that accounts for care within the violence of colonial ruptures between human/nonhuman, life/death, and life/nonlife. Here, decolonization does not stand as simply a metaphor (Tuck and Yang 2012). Returning and caretaking enact small moments of repatriation and land reclamation that side-step settler bureaucracies, even as these acts are contingent on uneven access to ancestral places within parcels of private property and public parks.

The concept of mound power turns colonial pretensions on their head, foregrounding Indigenous futures emergent in the ruins of settler states. Mounds may migrate or be mined for dirt fill, but the cement infrastructure of colonial nation-states cracks and crumbles. Such a long view helps foreground the slow processes in which mound power operates as a source of hope for life in the ruins of settler states. Some may ask how this perspective demands a rethinking of the relationship between archaeology, cultural anthropology, and Native American and Indigenous Studies (NAIS). Of course, these are not equal claims made on a level playing field. A dose of modesty proves essential: What is anthropology from the vantage of the deep durations of mound power, which renders even colonial orders so fleeting? At the same time, migrating mounds provide a deep genealogy for Indigenous archaeologies, calling attention to movements of soils that generate multiple, at times competing temporalities. Without erasing the real antagonisms between these fields, this idea subordinates anthropology within NAIS, as encompassed and located within Indigenous archaeologies that are much older than how the discipline is conceived within Eurocentric intellectual genealogies. To adapt Eve Tuck and K. Wayne Yang (2012), mound power is not accountable to anthropological futurities, but it does account for the deep histories of Indigenous archaeologies.

The relationship between mound and settler power likewise demands a rethinking of political philosophy, articulating an expansive Indigeneity not contained or captured by the settler state and that recognizes the fleeting nature of the colonial moment. Mounds offer hope for when the colonial moment is a painful memory. While critical scholarship has inquired into the social possibilities afforded by ruins in a moment of proliferating environmental catastrophe (e.g., Tsing 2015; Haraway 2016), such frameworks often fail to account for the decolonial possibilities (and responsibilities to land) enacted by mound power. A mound in Okeeheepkee is graded away for a machine shop but finds its way to the Pvlvcekolv ceremonial fire. Ancestors at Fusihatchee call on descendants for care and reopen 
Indigenous futures together. In these ways, mound power demystifies the hubris of colonial claims to completion and permanence. These force relations demand a rethinking of the temporalities of Indigenous governance as they interpolate Pvlvcekolv people (and sometimes settlers such as me) within Indigenous legal orders (Todd 2018) articulated not through coercive regulations but animate earth (Watts 2013). As such, a deep temporal perspective helps recognize Indigenous political formations that do not operate in linear time and that encompass but are not exhausted by settler colonialism. If settler colonialism is a system of organized apocalypse and ruination, then the ruins of colonial orders (in the remaining two senses) are also sites of Indigenous life and governance. In short, mound power animates resurgent possibilities of life beyond settler nation-states.

As mounds draw descendants into ancestral movements, the living and the dead reach out to one another, reopening Indigenous futures together within the contradictory spaces afforded by settler ruins and animate earth. These Indigenous archaeologies are enacted through practices of returning to place (Clifford 2013; Howe 2014) and cultivating resurgence (Alfred 2005; L. Simpson 2011): a "flourishing of an Indigenous inside" and an "art of starting over," in the sense of Indigenous renewal ceremonies that rebalance the world. This does not imply an ahistorical adoption of "ancestral ways of life" but rather a breathing of life into ancestral relationalities - a renewing of relationships with ancestral presences as agents in their own right. In these ways, mound power articulates self-determining modes of life irreducible to settler governance and demands a fundamental reordering of archaeological questions, methods, and objectives to center the loving labor of caring for wounded landscapes and making life together in the ruins of empires.

The land heals itself, even as the infrastructure of the settler state collapses into the Tallapoosa.

\begin{abstract}
This article theorizes the uneven entanglements between settler processes of ruination, a dynamic structured by regimes of history/prehistory, life/death, and life/ nonlife, and "mound power," or the force relations exercised by Indigenous landscapes as animate beings in their own right. I draw on research with members of a community in the U.S. South who claim Muskogee ancestry, visiting ancestral mound or earthwork and shellwork sites built over the past six thousand years. Wounded by ongoing colonial violence, these landscapes call out to descendants, drawing them into ancestral movements and relations of care. In these moments, ancestral sites refuse to be fixed within terminal chronological periods removed from a settled present, enrolling descendants into Indigenous space-times that dramatically exceed colonial
\end{abstract}


timescales and temporalities. Drawing on this deep historical perspective, this article articulates a modest hope for the ways Indigenous landscapes, as agentive beings, animate decolonial possibilities for life in the ruins of colonial empires. [temporality; landscape; southeastern United States; Native American and Indigenous peoples; archaeological ethnography; animacy; care; settler colonialism; the Anthropocene]

\section{NOTES}

Acknowledgments I would like to thank my Pvlvcekolv hosts and teachers who supported my research, shared their knowledge, and pushed me to ask what it means to live and do research in good relation on Indigenous land. Many community members reviewed this article and provided important feedback. Kasey Keeler organized a symposium at the University of Virginia in 2018, where I presented an early draft of this essay. There, I met J. K haulani Kauanui, who was instrumental in pushing me to publish this argument; Coll Thrush, who offered important insights about the political implications of language such as being "enrolled" into deep time; and Jessica Cattelino, who helped me think through the political and economic implications of my argument. My students at Brandeis have inspired and helped me engage more deeply with critical theories of settler colonialism and Indigenous visions of governance beyond nation-state models. I workshopped many of these ideas in Anna Brickhouse's "The Americas and/as Catastrophe" seminar through the Virginia Foundation for the Humanities. My advisor, Jeff Hantman, has worked with me patiently over the years to help me grow as a scholar and a person. China Schertz guided my engagement with the anthropology of care. Jim Igoe and Kath Weston guided me through critiques of the anthropological turn. Aileen Walsh helped identify places where I had reproduced a colonial orientation by taking Eurocentric ontologies and epistemologies as the norm and othering Indigenous ways of knowing/being. Martha Caldwell, Julia Haines, Myranda Pierce, and Gwendolyn Bright provided important editorial feedback on drafts of this article. The editors of Cultural Anthropology and anonymous peer reviewers helped me tremendously to clarify and sharpen the argument, giving me lifelong teachings about the relationship between ethnography and theory, as well as the subtle contradictions of recognition at play in this particular context. Funding for this research was provided by the National Science Foundation Cultural Anthropology Program (Doctoral Dissertation Research Improvement Grant \#1528653), the Wenner-Gren Foundation (Dissertation Fieldwork Grant \#9121), the American Philosophical Society Phillips Fund, the Explorers Club Washington Group, and the University of Virginia Institute of the Humanities and Global Cultures.

1. I use the term Native American as a broad umbrella for Indigenous peoples in the continental United States, parallel to other regionally specific terms such as First Nations. I use the term Indigenous to refer to global identities with specifically politicized connotations. I speak of peoples and nations to foreground issues of sovereignty, pointing to histories of nation-to-nation treaty making and political visions ordered around what Glen Sean Coulthard $(2014,65)$ calls self-determining modes of life.

2. Interpolation refers to the act of hailing others into relationship as a specific subject position (or kind of social role or social being). The archetypal example is turning to face a policeman who "hails" you, and in doing so, being fixed into the subject position of a citizen, potential criminal, and target of policing (Althusser 2001, 117-18).

3. In previous published work, I referred to this community using the Mvskoke-language pseudonym, Talwa. Due to the small size of the community, I did so to preserve the privacy of community members. Indeed, living in the post-Removal South has historically meant practicing Muskogee ways in private, outside the gaze of the settler public. However, colleagues noted that the pseudonym obscures the place and relationships from which I write. As an alternative, I use the ancestral Mvskoke-language name of the community, Pvlvcekolv, here to mediate both these concerns. This decision was made in 
conversation with the community leadership and brings my work into closer conversation with other scholars writing about Pvlvcekolv people (Koons 2019).

4. For a more thorough review, see David G. Anderson and Kenneth E. Sassaman (2012); George R. Milner (2004). On the Middle Woodland, see Elliot M. Abrams (2009), Christopher Carr and D. Troy Case (2006), and Alice P. Wright (2017). On the Mississippian, see John H. Blitz (2010) and Charles R. Cobb (2003).

5. "Disappearing Waters," referring to the lake, which periodically drains into the Florida aquifer (Bloch 2014, 88).

6. Radiocarbon dating measures the decay of carbon-14 isotopes, which can be extrapolated to calendrical dates within a given confidence interval. While these dates are given with only a 1 -sigma (68 percent) confidence interval, this suffices to illustrate my argument.

\section{REFERENCES}

Abrams, Elliot M.

2009 "Hopewell Archaeology: A View from the Northern Woodlands." Journal of Archaeological Research 17: 169-204. https://doi.org/10.1007/s10814-008-9028-0.

Alfred, Taiaiake

1999 Peace, Power, Righteousness: An Indigenous Manifesto. Oxford: Oxford University Press.

2005 Wasáse: Indigenous Pathways of Action and Freedom. Toronto: University of Toronto Press.

Allen, Chadwick

2015a “Performing Serpent Mound: A Trans-Indigenous Meditation.” Theatre Journal 67, no. 3: 391-411. http://doi.org/10.1353/tj.2015.0096.

2015b "Re-scripting Indigenous America: Earthworks in Native Art, Literature, Community." In Twenty-First Century Perspectives on Indigenous Studies: Native North America in (Trans)Motion, edited by Birgit Däwes, Karsten Fitz, and Sabine N. Meyer, 127-47. New York: Routledge.

Althusser, Louis

2001 Lenin and Philosophy and Other Essays. Translated by Ben Brewster. New York: New York University Press.

Anderson, David G., and Kenneth E. Sassaman

2012 Recent Developments in Southeastern Archaeology: From Colonization to Complexity. Washington, D.C.: Society for American Archaeology Press.

Atalay, Sonya

2006 “Indigenous Archaeology as Decolonizing Practice." American Indian Quarterly 30, nos. 3-4: 280-310.

Biehl, João

2005 Vita: Life in a Zone of Social Abandonment. Photographs by Torben Eskerod. Berkeley: University of California Press.

Blitz, John H.

2010 "New Perspectives in Mississippian Archaeology." Journal of Archaeological Research 18: 1-39. https://doi.org/10.1007/s10814-009-9033-y.

Bloch, Lee

2014 "The Unthinkable and the Unseen: Community Archaeology and Decolonizing Social Imagination at Okeeheepkee, or the Lake Jackson Site." Archaeologies 10: 70-106. https://doi.org/10.1007/s11759-014-9251-x.

2018 Sweetgum's Amber: Animate Mound Landscapes and the Nonlinear Longue Durée in the Native South. PhD diss., University of Virginia.

2019 "Oral Traditions and Mounds, Owls and Movement at Poverty Point: An Archaeological Ethnography of Multispecies Embodiments and Everyday Life." Journal of Social Archaeology 19, no. 3: 356-78. https://doi. org/10.1177\%2F1469605319846985. 
Bruyneel, Kevin

2007 The Third Space of Sovereignty: The Postcolonial Politics of U.S.-Indigenous Relations. Minneapolis: University of Minnesota Press.

Carr, Christopher, and D. Troy Case, eds.

2006 Gathering Hopewell: Society, Ritual and Interaction. New York: Springer.

Cipolla, Craig N., James Quinn, and Jay Levy

2019 "Theory in Collaborative Indigenous Archaeology: Insights from Mohegan." American Antiquity 84, no. 1: 127-42. https://doi.org/10.1017/aaq.2018.69.

Clark, John E.

2004 "Surrounding the Sacred: Geometry and Design of Early Mound Groups as Meaning and Function." In Signs of Power: The Rise of Cultural Complexity in the Southeast, edited by Jon L. Gibson and Philip J. Carr, 214-33. Tuscaloosa:

Clifford, James University of Alabama Press.

2013 Returns: Becoming Indigenous in the Twenty-First Century. Cambridge, Mass.: Harvard University Press.

Cobb, Charles R.

2003 "Mississippian Chiefdoms: How Complex?" Annual Review of Anthropology 32: 6384. https://doi.org/10.1146/annurev.anthro.32.061002.093244.

Colwell-Chanthaphonh, Chip, and T. J. Ferguson, eds.

2008 Collaboration in Archaeological Practice: Engaging Descendant Communities. Lanham, Md.: AltaMira.

Coulthard, Glen Sean

2014 Red Skin, White Masks: Rejecting the Colonial Politics of Recognition. Minneapolis: University of Minnesota Press.

Cruikshank, Julie

2005 Do Glaciers Listen? Local Knowledge, Colonial Encounters, and Social Imagination. Vancouver: University of British Columbia Press.

Davis, Heather, and Zoe Todd

2017 "On the Importance of a Date, or, Decolonizing the Anthropocene." ACME: An International Journal for Critical Geographies 16, no. 4: 761-80. https://acmejournal.org/index.php/acme/article/view/1539.

Dawdy, Shannon Lee

2010 "Clockpunk Anthropology and the Ruins of Modernity." Current Anthropology 51,

Dillon, Grace L. no. 6: 761-93. https://www.doi.org/10.1086/657626.

2012 "Imagining Indigenous Futurisms." In Walking the Clouds: An Anthology of Indigenous Science Fiction, edited by Grace L. Dillon, 1-12. Tucson: University of Arizona Press.

Dowdall, Katherine M., and Otis O. Parrish

2003 “A Meaningful Disturbance of Earth.” Journal of Social Archaeology 3, no. 1: 99133. https://doi.org/10.1177\%2F1469605303003001101.

Ethridge, Robbie

2003 Creek Country: The Creek Indians and Their World. Chapel Hill: University of North Carolina Press.

Ethridge, Robbie, and Sheri M. Shuck-Hall, eds.

2009 Mapping the Mississippian Shatter Zone: The Colonial Indian Slave Trade and Regional Instability in the American South. Lincoln, Neb.: University of Nebraska Press.

Ferguson, T. J., and Chip Colwell-Chanthaphonh

2006 History Is in the Land: Multivocal Tribal Traditions in Arizona's San Pedro Valley. Tucson: University of Arizona Press.

Foster, H. Thomas, II

2007 Archaeology of the Lower Muskogee Creek Indians, 1715-1836. With contributions by Mary Theresa Bonhage-Freund and Lisa O'Steen. Tuscaloosa: University of Alabama Press. 
Garcia, Angela

2010 The Pastoral Clinic: Addiction and Dispossession along the Rio Grande. Berkeley: University of California Press.

Han, Clara

2012 Life in Debt: Times of Care and Violence in Neoliberal Chile. Berkeley: University of California Press.

Haraway, Donna J.

2016 Staying with the Trouble: Making Kin in the Chthulucene. Durham, N.C.: Duke University Press.

Howe, LeAnne

2014 "Embodied Tribalography: Mound Building, Ball Games, and Native Endurance in the Southeast." Studies in American Indian Literatures 26, no. 2: 75-93. https://muse. jhu.edu/article/548056.

Jones, B. Calvin

1982 "Southern Cult Manifestations at the Lake Jackson Site, Leon County, Florida: Salvage Excavation of Mound 3.” Midcontinental Journal of Archaeology 7, no. 1: 3-44. https://www.jstor.org/stable/20707879.

Koons, Ryan A.

2019 "Becoming Avian in the Anthropocene: Performing the Feather Dance and the Owl Dance at Pvlvcekolv." Humanimalia 10, no. 2: 95-127. https://www.depauw. edu/humanimalia/issue\%2020/koons.html.

Laluk, Nicholas C.

2017 "The Indivisibility of Land and Mind: Indigenous Knowledge and Collaborative Archaeology within Apache Contexts.” Journal of Social Archaeology 17, no. 1: 92 112. https://doi.org/10.1177\%2F1469605317690082.

Larsen, Soren C., and Jay T. Johnson

2017 Being Together in Place: Indigenous Coexistence in a More Than Human World. Minneapolis: University of Minnesota Press.

Lightfoot, Kent G.

1995 "Cultural Contact Studies: Redefining the Relationship between Prehistoric and Historical Archaeology." American Antiquity 60, no. 2: 199-217. https://doi. org/10.2307/282137.

Marrinan, Rochelle A.

2012 "Fort Walton in the Tallahassee Hills." In Late Prehistoric Florida: Archaeology at the Edge of the Mississippian World, edited by Keith Ashley and Nancy Marie White, 186-230. Gainesville: University of Florida Press.

Marrinan, Rochelle A., and Nancy Marie White

2007 "Modeling Fort Walton Culture in Northwest Florida." Southeastern Archaeology 26, no. 2: 292-318.

McNiven, Ian J.

2016 “Theoretical Challenges of Indigenous Archaeology: Setting an Agenda." American Antiquity 81, no. 1: 27-41. https://doi.org/10.7183/0002-7316.81.1.27.

Miller, Jay

2015 Ancestral Mounds: Vitality and Volatility of Native America. Lincoln: University of Nebraska Press.

Milner, George R.

2004 The Moundbuilders: Ancient Peoples of Eastern North America. London: Thames and Hudson.

Mojica, Monique

2012 "In Plain Sight: Inscripted Earth and Invisible Realities." In New Canadian Realisms: New Essays on Canadian Theatre, Volume 2, edited by Roberta Barker and Kim Solga, 218-42. Toronto: Playwrights Canada Press.

Ortmann, Anthony L.

2010 "Placing the Poverty Point Mounds in Their Temporal Context." American Antiquity 75, no. 3: 657-78. https://doi.org/10.7183/0002-7316.75.3.657. 
Pauketat, Timothy R.

2007 Chiefdoms and Other Archaeological Delusions. Lanham, Md.: AltaMira.

Payne, Claudine

1994 "Mississippian Capitals: An Archaeological Investigation of Precolumbian Political Structure." PhD diss., University of Florida.

Povinelli, Elizabeth A.

2016 Geontologies: A Requiem to Late Liberalism. Durham, N.C.: Duke University Press.

Rifkin, Mark

2017 Beyond Settler Time: Temporal Sovereignty and Indigenous Self-Determination. Durham, N.C.: Duke University Press.

Sassaman, Kenneth E.

2005 "Poverty Point as Structure, Event, Process." Journal of Archaeological Method and Theory 12: 335-64. https://doi.org/10.1007/s10816-005-8460-4.

2012 "Futurologists Look Back." Archaeologies 8: 250-68. https://doi.org/10.1007/ s11759-012-9205-0.

Saunders, Joe W., Rolfe D. Mandel, C. Garth Sampson, Charles M. Allen, E. Thurman Allen, Daniel A. Bush, James K. Feathers, et al.

2005 "Watson Brake, A Middle Archaic Mound Complex in Northeast Louisiana." American Antiquity 70, no. 4: 631-68. https://doi.org/10.2307/40035868.

Saunt, Claudio

1999 A New Order of Things: Property, Power, and the Transformation of the Creek Indians, 1733-1816. Cambridge, UK: Cambridge University Press.

Scheiber, Laura L., and Mark D. Mitchell, eds.

2010 Across a Great Divide: Continuity and Change in Native North American Societies, 1400 1900. Tucson: University of Arizona Press.

Schmidt, Peter R., and Stephen A. Mrozowski, eds.

2013 The Death of Prehistory. Oxford: Oxford University Press.

Schneider, Tsim D.

2015 "Placing Refuge and the Archaeology of Indigenous Hinterlands in Colonial California." American Antiquity 80, no. 4: 695-713. https://doi.org/10.7183/00027316.80.4.695.

Seinfeld, Daniel M., Daniel P. Bigman, John Grant Stauffer, and Jesse C. Nowak

2015 "Mound Building at Lake Jackson (8LE1), Tallahassee, Florida: New Insights from Ground Penetrating Radar." Southeastern Archaeology 34, no. 3: 220-36. https:// doi.org/10.1179/2168472315Y.0000000012.

Silliman, Stephen W., ed.

2008 Collaborating at the Trowel's Edge: Teaching and Learning in Indigenous Archaeology. Tucson: University of Arizona Press.

Simpson, Audra

2014 Mohawk Interruptus: Political Life across the Borders of Settler States. Durham, N.C.: Duke University Press.

Simpson, Leanne Betasamosake

2011 Dancing on Our Turtle's Back: Stories of Nishnaabeg Re-creation, Resurgence and a New Emergence. Winnipeg: Arbeiter Ring.

Smith, Claire, and H. Martin Wobst, eds.

2005 Indigenous Archaeologies: Decolonizing Theory and Practice. New York: Routledge.

Stevenson, Lisa

2009 "The Suicidal Wound and Fieldwork among Canadian Inuit." In Being There: The Fieldwork Encounter and the Making of Truth, edited by John Borneman and Abdellah Hammoudi, 55-76. Berkeley: University of California Press.

2014 Life Beside Itself: Imagining Care in the Canadian Arctic. Berkeley: University of California Press.

Stoler, Ann Laura

2008 "Imperial Debris: Reflections on Ruins and Ruination." Cultural Anthropology 23, no. 2: 191-219. https://doi.org/10.1111/j.1548-1360.2008.00007.x. 
Todd, Zoe

2018 "Refracting the State through Human-Fish Relations: Fishing, Indigenous Legal Orders and Colonialism in North/Western Canada." Decolonization: Indigeneity, Education, and Society 7, no. 1: 60-75.

Tsing, Anna Lowenhaupt

2015 The Mushroom at the End of the World: On the Possibility of Life in Capitalist Ruins. Princeton, N.J.: Princeton University Press.

Tuck, Eve, and K. Wayne Yang

2012 "Decolonization Is Not a Metaphor." Decolonization: Indigeneity, Education and Society 1, no. 1: 1-40. https://jps.library.utoronto.ca/index.php/des/article/ view/18630.

Watkins, Joe

2000 Indigenous Archaeology: American Indian Values and Scientific Practice. Walnut Creek, Calif.: AltaMira.

Watts, Vanessa

2013 "Indigenous Place-Thought and Agency amongst Humans and Non Humans (First Woman and Sky Woman Go on a European World Tour!).” Decolonization: Indigeneity, Education, and Society 2, no. 1: 20-34. https://jps.library.utoronto.ca/ index.php/des/article/view/19145.

Whyte, Kyle P.

2017 "Our Ancestors' Dystopia Now: Indigenous Conservation and the Anthropocene." In The Routledge Companion to the Environmental Humanities, edited by Ursula K. Heise, Jon Christensen, and Michelle Niemann, 206-15. New York: Routledge.

2018 "Indigenous Science (Fiction) for the Anthropocene: Ancestral Dystopias and Fantasies of Climate Change Crises." Environment and Planning E: Nature and Space 1, nos. 1-2: 224-42. https://doi.org/10.1177\%2F2514848618777621.

Wolfe, Patrick

2006 "Settler Colonialism and the Elimination of the Native." Journal of Genocide Research 8, no. 4: 387-409. https://doi.org/10.1080/14623520601056240.

Wright, Alice P.

2017 "Local and 'Global' Perspectives on the Middle Woodland Southeast." Journal of Archaeological Research 25: 37-83. https://doi.org/10.1007/s10814-016-9096-5. 